\title{
SEMI-ANALYTICAL SOLUTION FOR FREE VIBRATION DIFFERENTIAL EQUATIONS OF CURVED GIRDERS
}

\author{
Y.SONG ${ }^{1}$, X. CHAI ${ }^{2}$
}

\begin{abstract}
In this paper, a semi-analytical solution for free vibration differential equations of curved girders is proposed based on their mathematical properties and vibration characteristics. The solutions of in-plane vibration differential equations are classified into two cases: one only considers variable separation of non-longitudinal vibration, while the other is a synthesis method addressing both longitudinal and non-longitudinal vibration using Rayleigh's modal assumption and variable separation method. A similar approach is employed for the outof-plane vibration, but further mathematical operations are conducted to incorporate the coupling effect of bending and twisting. In this case study, the natural frequencies of a curved girder under different boundary conditions are obtained using the two proposed methods, respectively. The results are compared with those from the finite element analysis (FEA) and results show good convergence.
\end{abstract}

Keywords: curved girder, free vibration, natural frequency, semi-analytical solution, variable separation

\section{INTRODUCTION}

The findings of dynamic characteristics on curved girders are fewer than those of static cases. Komatsu and Nakai [1-2] studied the free vibration and forced vibration of a horizontal curved Igirder and a box girder using Vlasov's differential equations and thin-walled box girder theory. Yoo [3] used the finite segment element method for spatial curved girders (where each node has 7 degrees of freedom) and analyzed natural frequencies considering section warping. Taking into consideration the difference between shear centre and centroid of cross-section, Kou et al. [4]

\footnotetext{
${ }^{1}$ Assistant Prof., PhD., Eng., Shanghai University of Engineering Science, Faculty of Urban Railway Transportation, 333 Longteng Rd, 201620 Shanghai, China, e-mail: songyumin@sues.edu.cn

${ }^{2}$ Prof., PhD., Eng., Shanghai University of Engineering Science, Faculty of Urban Railway Transportation, 333

Longteng Rd, 201620 Shanghai, China, e-mail: cxdyj@163.com
} 
extended the method to thin-walled box girders. Howson and Jemah's work [5] focused on the exact out-of-plane natural frequencies of curved girders. By employing Vlasov's differential equations and Hamilton's principle, Shan [6] deduced the vibration differential equation on curved girders, and solved the equations using Fourier transform and Laplace transform. Yang and $\mathrm{Wu}$ [7] studied the forced vibration of curved girders. As common ground of this research, the deduced vibration differential equations from static Vlasov's differential equations of curved girders, though, lack strict derivation. The vibration differential equations for curved girders were derived according to Hamilton's principle and Lagrange's equation, and are applicable only to curved Timoshenko beams in the axial coordinate system.

Great efforts have been made over the last 40 years to study the train-track and vehicle-bridge dynamic interactions. Fryba L [8] used the moving-force model to study the dynamic interaction, while Akin JE and Mofid M [9] chose the moving-mass model. The sprung mass model was applied in the simulation by Pesterev AV and Bergman LA [10]. In recent years, José et al. [11] defined a model for a flexible wheelset running on a flexible curved track. Song, Wu, and Elias [12-16] studied the dynamic characteristics of curved girders and the coupling vibration of vehicle-bridge systems on curved girders. In their studies, the methods of mathematical physics were used to derive the vibration differential equations of curved girders, as well as to prove the equations, but the solution has not been completed yet.

In this paper, the completed solution of vibration differential equations of curved girders is presented. Case studies are carried out using the proposed method. The results are validated using finite element analysis (FEA) with satisfied convergence.

\section{FREE VIBRATION DIFFERENTIAL EQUATIONS OF CURVED GIRDERS}

Firstly, the coordinate system is set as follows: forward of $\mathrm{x}$ is along the tangent direction of the curved girder axis; forward of y points to the curved girder's circle's centre; forward of $\mathrm{z}$ is vertical down. These are consistent with the right-hand rule. Moreover, some basic assumptions about the curved girder in this study are adopted as follows:

1. The curved girder has constant section and homogeneous material, and the curvature radius is constant.

2. The cross-section of the curved girder has a vertically symmetrical axis, and the centroid coincides with the shear centre. 
3. The curvature radius of the curved girder is much larger than the cross-sectional size, length, and height.

The coordinate system and internal forces of a curved girder segment are shown in Fig. 1.

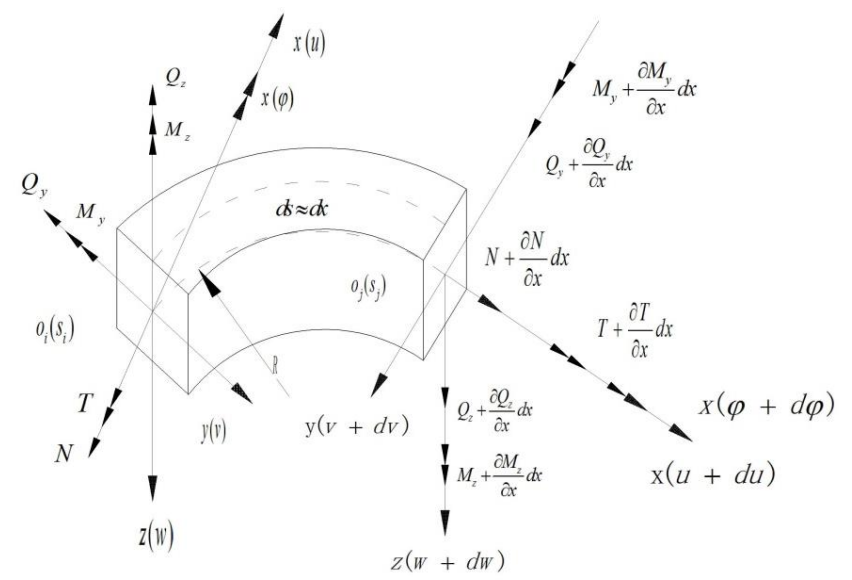

Fig. 1 Curvilinear coordinate system, internal forces, and displacements of an infinitesimal segment

The free vibration differential equations of curved girders have been derived as follows [14]:

$$
\begin{gathered}
E I_{z}\left(v^{(V)}+\frac{2}{R^{2}} v^{\prime \prime \prime}+\frac{1}{R^{4}} v^{\prime}\right)=\frac{m}{R} \ddot{u}-m \ddot{v^{\prime}} \\
\left(E I_{y}+\frac{E I_{\omega}}{R^{2}}\right) w^{\prime \prime \prime \prime}-\frac{G I_{d}}{R^{2}} w^{\prime \prime}+\frac{E I_{\omega}}{R} \varphi^{\prime \prime \prime}-\frac{E I_{y}+G I_{d}}{R} \varphi^{\prime \prime}+m \ddot{w}=0 \\
\frac{E I_{\omega}}{R} w^{\prime \prime \prime \prime}-\frac{E I_{y}+G I_{d}}{R} w^{\prime \prime}+E I_{\omega} \varphi^{\prime \prime \prime \prime}-G I_{d} \varphi^{\prime \prime}+\frac{E I_{y}}{R^{2}} \varphi+\rho I_{d} \ddot{\varphi}=0
\end{gathered}
$$

The general formation can be obtained after further derivation [14], and is shown in Eq. (2.4) and Eq. (2.5).

$$
\begin{aligned}
& \left(v^{(\mathrm{V})}+\frac{2}{R^{2}} v^{\prime \prime \prime \prime}+\frac{1}{R^{4}} v^{\prime}\right)+\frac{m}{E I_{z}} \ddot{v^{\prime}}=\frac{1}{R} \frac{m}{E I_{z}} \ddot{u} \\
& w^{\prime \prime \prime \prime}+\frac{1}{R^{2}} w^{\prime \prime}+\frac{m}{E I_{y}} \ddot{w}=\frac{1}{R}\left(\varphi^{\prime \prime}+\frac{\varphi}{R^{2}}+\frac{\rho I_{d}}{E I_{y}} \ddot{\varphi}\right)
\end{aligned}
$$

where: 
$\mathrm{u}$ - tangential (longitudinal) displacement, $\mathrm{v}$ - lateral (radial) displacement, $\mathrm{w}$ - vertical displacement, $\varphi-$ torsion angle, $\mathrm{m}$ - mass per unit length, $\rho$ - mass density of material, $I_{x}, I_{y}$ - sectional moment of inertia around the $\mathrm{x}$ - and $\mathrm{y}$-axis respectively, $I_{\omega}$ - warping torsion constant of section (torsional warping constant), $I_{d}$ - torsion constant of section, $E I_{\omega} \beta^{\prime \prime}-$ bi-moment of restrained torsion, $G I_{d} \kappa_{z}-$ Saint-Venant torsion moment, R - radius of curvature, E - modulus of elasticity, (') - partial derivatives of the coordinate $\mathrm{z},(\bullet)$ - partial derivative of the time $\mathrm{t}$.

\section{METHODS FOR SOLVING FREE VIBRATION DIFFERENTIAL EQUATIONS}

\subsection{FREE IN-PLANE VIBRATION}

\subsubsection{NON-CONSIDERING LONGITUDINAL VIBRATION}

Some secondary factors can be neglected for civil engineering structures. It is reasonable to neglect axial deformation (assuming $u=0$ ), as bridge section axial tension and compression stiffness is large, and the axial deformation is relatively small. Hence, the formula without considering longitudinal vibration can be written as follows [15]:

$$
\frac{1}{R} \frac{d^{2} v}{d t^{2}}=\frac{d u}{d x} \frac{d^{2} u}{d t^{2}}
$$

By substituting Eq. (3.1) into Eq. (2.1), a sixth-order partial differential equation with constant coefficients is obtained for the free longitudinal vibration:

$$
v^{(\mathrm{VI})}+\frac{2}{R^{2}} v^{\prime \prime \prime}+\frac{1}{R^{4}} v^{\prime \prime}=\frac{m}{E I_{z}}\left(\frac{1}{R^{2}}-v^{\prime \prime}\right) \ddot{v}
$$

The coupling term of the curvature and its acceleration on lateral bending (that is $v^{\prime \prime} \bar{v}$ ) can be ignored under the assumption of small deformation. Thus Eq. (3.2) can be further simplified as:

$$
v^{(\mathrm{VI})}+\frac{2}{R^{2}} v^{\prime \prime \prime}+\frac{1}{R^{4}} v^{\prime \prime}=\frac{1}{R^{2}} \frac{m}{E I_{z}} \ddot{v}
$$


Eq. (3.3) is a sixth-order ordinary differential equation with constant coefficients, which can be solved more easily.

\subsubsection{CONSIDERING LONGITUDINAL VIBRATION}

There is no cross-term regarding vibration displacement variables $u$ and $v$ in Eq. (2.1) (such as $u \cdot v$ or $u v^{-1}$ ), hence these two variables are independent on time. A modal shape function of longitudinal vibration can be assumed via Rayleigh's modal assumption method. The displacement function $\mathrm{u}$ is assumed as presented in Eq. (3.4), and a high ordinary differential equation with a constant coefficient can be obtained by substituting it into Eq. (2.1).

$$
\begin{cases}u(x, t)=\sin (n \pi x / L) U_{0} \cos (\omega t) & \text { (simple-supported or fixed curved beam) } \\ u(x, t)=\sin ((2 n-1) \pi x / 2 L) U_{0} \cos (\omega t) & \text { (cantilever curved beam) }\end{cases}
$$

where:

$U_{0}$ - max-amplitude (determined by initial condition), $L$ - equivalent length of curved girder, $\omega$ - circular frequency of vibration.

The three types of boundary conditions in Eq. (3.4) are as follows:

1. simply-supported curved girder:

$$
u(0, t)=0, u(L, t) \neq 0, v(0, t)=0, v(L, t) \neq 0, w(0, t)=0, w(L, t)=0, \varphi(0, t)=0, \varphi(L, t)=0
$$

2. fixed-end curved girder:

$$
u(0, t)=0, u(L, t)=0, v(0, t)=0, v(L, t)=0, w(0, t)=0, w(L, t)=0, \varphi(0, t)=0, \varphi(L, t)=0
$$

3. cantilever curved girder:

$$
u(0, t)=0, u(L, t) \neq 0, v(0, t)=0, v(L, t) \neq 0, \quad w(0, t)=0, w(L, t) \neq 0, \varphi(0, t)=0, \varphi(L, t) \neq 0
$$

\subsection{FreE OUT-OF-PLANE Vibration}

By merging Eq. (2.2) and Eq. (2.3), a new free out-of-plane vibration equation can be obtained as follows:

$$
A \varphi^{(V I)}+\left(\frac{2 A}{R^{2}}-D\right) \varphi^{\prime \prime \prime}+\frac{1}{R^{2}}\left(\frac{A}{R}-2 D\right) \varphi^{\prime \prime}-\frac{D}{R^{4}} \varphi=\frac{a}{R^{2}}\left(1-\frac{A+R^{2} B}{D} \varphi^{\prime \prime}\right) \ddot{\varphi}-\frac{b}{R}\left(1-A w^{\prime \prime}\right) \ddot{w}
$$

where:

$A=E I_{\omega} ; \quad B=E I_{y} ; \quad D=G I_{d} ; \quad a=\rho G I_{d}^{2} / E I_{y} ; \quad b=m\left(E I_{y}+G I_{d}\right) / E I_{y}$ 
It can be deduced that when the radius of a curved girder tends to Infinity (that is $R \rightarrow \infty$ ), Eq. (3.5) can further degenerate into the torsional vibration differential equation of straight girders as shown below, which in return proves that Eq. (3.5) is correct.

$$
E I_{\omega} \varphi^{\prime \prime \prime}-G I_{d} \varphi^{\prime \prime}+\rho I_{d} \ddot{\varphi}=0
$$

Using the same methodology as mentioned above, the coupling term of curvature and its acceleration on vertical bending (that is $w^{\prime \prime} w_{w}$ ), and the torsion-rate and its acceleration (that is $\varphi^{\prime \prime} \ddot{\varphi}$ ) can be ignored, which ends up in Eq. (3.6), and could be further simplified to Eq. (3.7).

$$
\begin{gathered}
A \varphi^{(I I)}+\left(\frac{2 A}{R^{2}}-D\right) \varphi^{\prime \prime \prime}+\frac{1}{R^{2}}\left(\frac{A}{R}-2 D\right) \varphi^{\prime \prime}-\frac{D}{R^{4}} \varphi=\frac{a}{R^{2}} \ddot{\varphi}-\frac{b}{R} \ddot{w} \\
\varphi^{(V I)}+\left(\frac{2}{R^{2}}-\frac{D}{A}\right) \varphi^{\prime \prime \prime}+\frac{1}{R^{2}}\left(\frac{1}{R}-\frac{2 D}{A}\right) \varphi^{\prime \prime}-\frac{D}{A R^{4}} \varphi=-\frac{a}{A R^{2}} \ddot{\varphi}+\frac{b}{A R} \ddot{w}
\end{gathered}
$$

There is no cross-term regarding vibration displacement variables $w$ and $\varphi$ in Eq. (3.7), such as $w \varphi$ or $w \varphi^{-1}$, hence these two variables are also independent on time. A modal shape function of vertical vibration can be derived via Rayleigh's modal assumption. The displacement function $w$ is obtained by Eq. (3.8), and a high ordinary non-homogeneous differential equation with constant coefficients can be achieved by substituting it into Eq. (3.7).

$$
\begin{cases}w(x, t)=\sin (n \pi x / L) W_{0} \cos (\omega t) & \text { (simple-supported or fixed curved beam) } \\ w(x, t)=\sin ((2 n-1) \pi x / 2 L) W_{0} \cos (\omega t) & \text { (cantilever curved beam) }\end{cases}
$$

where:

$W_{0}$ - max-amplitude determined by initial condition, $L$ - equivalent length of curved girder, $\omega$ - circular frequency of vibration. 


\section{SOLUTIONS OF FREE VIBRATION DIFFERENTIAL EQUATIONS}

\subsection{FREE IN-PLANE VIBRATION}

\subsubsection{NON-CONSIDERING LONGITUDINAL VIBRATION}

Eq. (3.3) (the free in-plane vibration differential equation without considering longitude vibration) can be solved through the variable separation method. By substituting vibration curve $v(x, t)=f(x) y(t)$ into it, a new formula can be obtained:

$$
\frac{f^{(\mathrm{VI})}(x)}{f(x)}+\frac{2}{R^{2}} \frac{f^{\prime \prime \prime}(x)}{f(x)}+\frac{1}{R^{4}} \frac{f^{\prime \prime}(x)}{f(x)}=-\frac{1}{R^{2}} \frac{m}{E I_{z}} \frac{\ddot{y(t)}}{y(t)}=\alpha^{6}
$$

Two ordinary differential equations can be derived from Eq. (4.1):

$$
\begin{gathered}
\ddot{y(t)}+\left(\alpha^{6} R^{2} E I_{z} / m\right) y(t)=0 \text { or } \ddot{y(t)}+\omega^{2} y(t)=0 ;\left(\omega^{2}=\alpha^{6} R^{2} E I_{z} / m\right) \\
f^{(\mathrm{VI})}(x)+\frac{2}{R^{2}} f^{\prime \prime \prime}(x)+\frac{1}{R^{4}} f^{\prime \prime}(x)-\alpha^{6} f(x)=0
\end{gathered}
$$

Eq. (4.2) is the vibration equation of an un-damped single degree of freedom system, and its generalized solution is:

$$
y(t)=y(0) \cos (\omega t)+(\dot{y(0)} / \omega) \sin (\omega t)
$$

Assuming the solution form of Eq. (4.3) is $f(x)=C e^{\lambda x}$, its characteristic equation with root $\lambda$ can be expressed as:

$$
\lambda^{6}+\frac{2}{R^{2}} \lambda^{4}+\frac{1}{R^{4}} \lambda^{2}-\alpha^{6}=0
$$


The six characteristic roots can be obtained using Cardano's method, and the complete results can be achieved by substituting the six characteristic roots into $f(x)=C e^{\lambda x}$ :

$$
f(x)=C_{1} e^{\lambda_{1} x}+C_{2} e^{\lambda_{2} x}+C_{3} e^{\lambda_{3} x}+C_{4} e^{\lambda_{4} x}+C_{5} e^{\lambda_{5} x}+C_{6} e^{\lambda_{6} x}
$$

where:

$C_{1}, C_{2}, C_{3}, C_{4}, C_{5}, C_{6}$ - coefficients determined by boundary conditions of curved girders.

Hence, the semi-analytical solution of the in-plane vibration of curved girders without considering longitude vibration can be written as follows:

$$
v(x, t)=\left(C_{1} e^{s_{1} x}+C_{2} e^{s_{2} x}+C_{3} e^{s_{3} x}+C_{4} e^{s_{4} x}+C_{5} e^{s_{5} x}+C_{6} e^{s_{6} x}\right)(y(0) \cos (\omega t)+(\dot{y(0)} / \omega) \sin (\omega t))
$$

\subsubsection{CONSIDERING LONGITUDE VIBRATION}

The non-homogeneous differential equation of in-plane vibration considering longitude vibration is obtained by substituting Eq. (3.4) into Eq. (2.4) as following:

$$
v^{(\mathrm{V})}+\frac{2}{R^{2}} v^{\prime \prime \prime}+\frac{1}{R^{4}} v^{\prime}+\frac{m}{E I_{z}} \ddot{v}=-\frac{m \omega^{2}}{R E I_{z}} U_{0} \sin \left(\frac{n \pi}{L} x\right) \cos (\omega t)
$$

The right-hand term $-\frac{m \omega^{2}}{R E I_{z}} U_{0} \sin \left(\frac{n \pi}{L} x\right) \cos (\omega t)$ in Eq. (4.5) can be used as the particular solution for the following homogeneous differential equation:

$$
v^{(\mathrm{V})}+\frac{2}{R^{2}} v^{\prime \prime \prime}+\frac{1}{R^{4}} v^{\prime}+\frac{m}{E I_{z}} \ddot{v}=0
$$

Using the variable separation method to solve with its forms of solution supposed as: 


$$
\left\{\begin{array}{l}
v(x, t)=f(x) y(t) \\
V(x, t)=v^{\prime}(x, t)=f^{\prime}(x) y(t)=F(x) y(t)
\end{array}\right.
$$

Substituting Eq. (4.7) into Eq. (4.6) yields:

$$
\frac{F^{\prime \prime \prime}(x)}{F(x)}+\frac{2}{R^{2}} \frac{F^{\prime \prime}(x)}{F(x)}+\frac{1}{R^{4}}=-\frac{m}{E I_{z}} \frac{\ddot{y}(t)}{y(t)}=\beta^{4}
$$

Two homogeneous differential equations can be derived from Eq. (4.8) as:

$$
\begin{gathered}
\ddot{y(t)}+\left(\beta^{4} E I_{z} / m\right) y(t)=0 \quad \text { or } \ddot{y(t)}+\omega^{2} y(t)=0 ;\left(\omega^{2}=\beta^{4} E I_{z} / m\right) \\
F^{\prime \prime \prime}(x)+\frac{2}{R^{2}} F^{\prime \prime}(x)+\left(\frac{1}{R^{4}}-\beta^{4}\right) F(x)=0
\end{gathered}
$$

The solution of Eq. (4.9) can be obtained easily:

$$
y(t)=B_{1} \cos (\omega t)+B_{2} \sin (\omega t)
$$

where:

constant $B_{1}$ and $B_{2}$ can be obtained based on the initial conditions of displacement and velocity.

The solution form of Eq. (4.10) is assumed as $F(x)=C e^{\lambda x}$, and then its characteristic equation with root $\lambda$ can be written as:

$$
\lambda^{4}+\frac{2}{R^{2}} \lambda^{2}+\left(\frac{1}{R^{4}}-\beta^{4}\right)=0
$$

Similar to 4.1.1, the complete solution of Eq. (4.10) could be expressed as:

$$
f(x)=\int F(x)+C_{5}=C_{1} e^{\lambda_{1} x}+C_{2} e^{\lambda_{2} x}+C_{3} e^{\lambda_{3} x}+C_{4} e^{\lambda_{4} x}+C_{5}
$$

where:

$C_{1}, C_{2}, C_{3}, C_{4}, C_{5}$ - coefficients determined by boundary conditions of curved girders. 
The semi-analytical solution of the in-plane vibration of curved girders considering longitude vibration can be written as follows:

$$
\left\{\begin{array}{l}
v(x, t)=f(x) y(t)-\left(m \omega^{2} / R E I_{z}\right) U_{0} \sin (n \pi x / L) \cos (\omega t) \\
f(x) y(t)=\left(C_{1} e^{s_{1} x}+C_{2} e^{s_{2} x}+C_{3} e^{s_{3} x}+C_{4} e^{s_{4} x}+C_{5}\right)\left(B_{1} \cos (\omega t)+B_{2} \sin (\omega t)\right)
\end{array}\right.
$$

\subsection{FREE OUT-OF-PLANE VIBRATION}

The non-homogeneous differential equation of the free out-of-plan vibration equation is obtained by substituting Eq. (3.8) into Eq. (3.7) as follows:

$$
\varphi^{(V I)}+\left(\frac{2}{R^{2}}-\frac{D}{A}\right) \varphi^{\prime \prime \prime}+\frac{1}{R^{2}}\left(\frac{1}{R}-\frac{2 D}{A}\right) \varphi^{\prime \prime}-\frac{D}{A R^{4}} \varphi+\frac{a}{A R^{2}} \ddot{\varphi}=\frac{b}{A R} W_{0} \omega^{2} \sin \left(\frac{n \pi}{L} x\right) \cos (\omega t)
$$

The right-hand term $\frac{b}{A R} W_{n} \omega^{2} \sin \left(\frac{n \pi}{L} x\right) \cos (\omega t)$ in Eq. (4.12) can be used as the particular solution of the following homogeneous differential equation:

$$
\varphi^{(V I)}+\left(\frac{2}{R^{2}}-\frac{D}{A}\right) \varphi^{\prime \prime \prime}+\frac{1}{R^{2}}\left(\frac{1}{R}-\frac{2 D}{A}\right) \varphi^{\prime \prime}-\frac{D}{A R^{4}} \varphi+\frac{a}{A R^{2}} \ddot{\varphi}=0
$$

The sum of the solution of homogeneous differential equation Eq. (4.13) and this particular solution is the solution of formula Eq. (4.12). The former is supposed to show $\varphi(x, t)=f(x) y(t)$, and Eq. (4.14) can be derived as follows using the variable separation method.

$$
\frac{f(x)^{(V I)}}{f(x)}+\left(\frac{2}{R^{2}}-\frac{D}{A}\right) \frac{f(x)^{\prime \prime \prime}}{f(x)}+\frac{1}{R^{2}}\left(\frac{1}{R}-\frac{2 D}{A}\right) \frac{f(x) "}{f(x)}-\frac{D}{A R^{4}}=-\frac{a}{A R^{2}} \frac{\ddot{y(t)}}{y(t)}=\kappa^{6}
$$

Two homogeneous differential equations can be derived from Eq. (4.14): 


$$
\begin{gathered}
\ddot{y(t)}+\left(\kappa^{6} A R^{2} / a\right) y(t)=0 \text { or } \ddot{y(t)}+\omega^{2} y(t)=0\left(\omega^{2}=A R^{2} \kappa^{6} / a\right) \\
f(x)^{(V I)}+\left(\frac{2}{R^{2}}-\frac{D}{A}\right) f(x){ }^{\prime \prime \prime}+\frac{1}{R^{2}}\left(\frac{1}{R}-\frac{2 D}{A}\right) f(x)^{\prime \prime}-\left(\frac{D}{A R^{4}}+\kappa^{6}\right) f(x)=0
\end{gathered}
$$

For Eq. (4.16), the coefficients can be set as: $p=\left(\frac{2}{R^{2}}-\frac{D}{A}\right) ; \quad q=\frac{1}{R^{2}}\left(\frac{1}{R}-\frac{2 D}{A}\right) ; \quad h=\left(\frac{D}{A R^{4}}+\kappa^{6}\right)$,

and it is then simplified to:

$$
f(x)^{(V I)}+p f(x)^{\prime \prime \prime}+q f(x)^{\prime \prime}-h f(x)=0
$$

The solution of Eq. (4.15) can be obtained easily:

$$
y(t)=B_{1} \cos (\omega t)+B_{2} \sin (\omega t)
$$

where:

constant $B_{1}$ and $B_{2}$ can be obtained according to the initial condition of displacement and velocity.

The solution form of Eq. (4.24) is assumed as $f(x)=C e^{\lambda x}$, and then its characteristic equation is:

$$
\lambda^{6}+p \lambda^{4}+q \lambda^{2}-h=0
$$

Similar to 4.1.1, the solution can be obtained as:

$$
f(x)=C_{1} e^{\lambda_{1} x}+C_{2} e^{\lambda_{2} x}+C_{3} e^{\lambda_{3} x}+C_{4} e^{\lambda_{4} x}+C_{5} e^{\lambda_{5} x}+C_{6} e^{\lambda_{6} x}
$$

where:

$C_{1}, C_{2}, C_{3}, C_{4}, C_{5}, C_{6}$ - coefficients determined by boundary conditions of curved girders.

Since the expression of the undetermined coefficients is complicated, a semi-analytical solution of the out-of-plane vibration of curved girders can be written as follows:

$$
\left\{\begin{array}{l}
\varphi(x, t)=f(x) y(t)+\left(b W_{0} \omega^{2} / A R\right) \sin (n \pi x / L) \cos (\omega t) \\
f(x) y(t)=\left(C_{1} e^{s_{1} x}+C_{2} e^{s_{2} x}+C_{3} e^{s_{3} x}+C_{4} e^{s_{4} x}+C_{5} e^{s_{5} x}+C_{6} e^{s_{6} x}\right)\left(B_{1} \cos (\omega t)+B_{2} \sin (\omega t)\right)
\end{array}\right.
$$


The above Eq. (4.4), Eq. (4.11), and Eq. (4.17) give the semi-analytical solutions of vibration differential equation of curved girders. The modal and frequency can be obtained according to the boundary conditions with the aid of a mathematics computer language.

\subsection{NUMERICAL CASE STUDY AND ANALYSIS}

A curved girder with a rectangular solid section is used in the numerical case study. Its radius is $R=100 \mathrm{~m}$, and the section size is $1.0 \mathrm{~m}$ in height and $2.0 \mathrm{~m}$ in width. The material is assumed to be steel, and $I_{d}, I_{\omega}$ are calculated as follows: $I_{d}=\int_{\mathrm{A}} r^{2} d A, I_{\omega}=\int_{\mathrm{A}} \omega^{2} d A$, where variable $r$ denotes the radius of the integral sub-region, and variable $\omega$ denotes the sectorial coordinate. The related parameters in this case study are: $\rho=7800 \mathrm{~kg} / \mathrm{m}^{3}, E=210 \times 10^{9} \mathrm{~Pa}, G=80 \times 10^{9} \mathrm{~Pa}, I_{d}=0.457 \mathrm{~m}^{4}, I_{\omega}$ $0=0.028 \mathrm{~m}^{6}$. Three types of boundary conditions are considered: cantilever curved girder, simplysupported curved girder, and fixed-end curved girder.

The first-order natural frequencies were solved using the proposed method and FEA in ANSYS, and the results are given in Table 1. The solid element Solid65 is employed for the FEA model. The girder is divided into 15 sub-blocks in the rectangular cross section, and further uniformly mapped along the length of the girder. The models of the cantilever curved girder and the simply-supported curved girder are shown in Fig. 2.

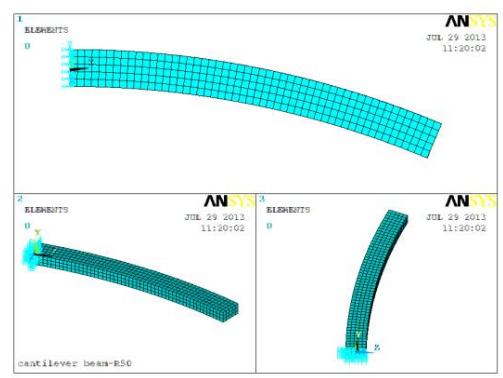

(a) cantilever curved girder

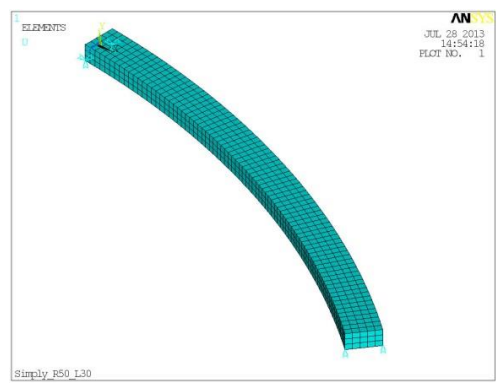

(b) simply-supported curved girder

Fig. 2. Finite element models of the curved girders in the case study 
Table 1. Comparisons of natural frequencies and modals from the proposed method and FEA (units: $H z$ )

\begin{tabular}{|c|c|c|c|c|c|c|c|c|}
\hline Categories & \multicolumn{4}{|c|}{ Out-of-Plane Vibration } & \multicolumn{3}{c|}{ In-Plane Vibration } \\
\hline Modal & \multicolumn{1}{|c|}{ Vertical Bending } & \multicolumn{2}{|c|}{ Twist Twisting } & \multicolumn{2}{c|}{ Lateral Bending ${ }^{1}$} & \multicolumn{2}{c|}{ Lateral Bending $^{2}$} \\
\hline Methods & $\begin{array}{c}\text { Proposed } \\
\text { Method }\end{array}$ & FEA & $\begin{array}{c}\text { Proposed } \\
\text { Method }\end{array}$ & FEA & $\begin{array}{c}\text { Proposed } \\
\text { Method }\end{array}$ & FEA & $\begin{array}{c}\text { Proposed } \\
\text { Method }\end{array}$ & FEA \\
\hline Cantilever & 1.7110 & 1.5303 & 22.571 & 22.234 & 3.0331 & 3.0362 & 3.1011 & 3.0362 \\
\hline $\begin{array}{c}\text { Simply- } \\
\text { Supported }\end{array}$ & 4.4673 & 4.1052 & 38.018 & 37.518 & 2.0252 & 2.0213 & 2.0721 & 2.0213 \\
\hline Fixed-end & 10.661 & 9.5382 & 46.321 & 44.859 & 20.811 & 20.819 & 21.223 & 20.819 \\
\hline
\end{tabular}

1. Non-Considering Longitudinal Vibration

2. Considering Longitudinal Vibration

In Table 1 it can be seen that results from the semi-analytical solutions agree well with those of the FEA, despite tolerable deviations. For the vibration modal of in-plane lateral bending, the firstorder natural frequencies obtained via semi-analytical solutions are consistent with those of the FEA for non-considering longitudinal vibration, while when considering the longitudinal vibration issue, the first-order natural frequencies via the method of semi-analytical solutions are slightly greater than those of the FEA. A possible explanation is that the assumed modal is equivalent to add constrains and enhance stiffness of the structure due to Rayleigh's modal assumption. When it comes to the vibration modal of vertical bending and twisting out of plane, the first-order natural frequencies via the method of semi-analytical solutions are greater than those via the method of FEA, and the maximum error is nearly $10 \%$. Through analysis, there might be two reasons for these results: one is the same as above, and the other is that the assumption of the vibration mode is fully unreasonable.

\section{CONCLUSION}

A semi-analytical solution for the free vibration differential equations of curved girders is proposed in this paper by combining Rayleigh's modal assumption and the variable separation method. Case studies of curved girders under three different boundary conditions are performed using the proposed method, followed by the comparison and validation using the FEA. Conclusions can be drawn as follows:

1. Taking into consideration the restrained torsion of curved girders, a more accurate solution could be achieved for engineering practices, especially for the detailed dynamic analysis of curved girders with thin-wall boxes. 
2. The free vibration differential equations of curved girders with restrained torsion have higher orders, up to 6 , which make it hard to obtain an analytical solution. As a result, numerical approximation works as a general approach, but it has some limitations. The proposed semianalytical solution based on the mechanical characteristics of curved girders is a more applicable and general approach for similar problems.

3. The solutions of high order partial differential equations have obvious mathematical characteristics. The proposed method in this paper is a useful exploration and attempt at a solution, and the possible improvement is still worth further study.

\section{ACKNOWLEDGEMENTS}

The author would like to gratefully acknowledge the financial support from the National Nature Science Foundation of China (Grant No. 51478258), and thanks are given here. 


\section{REFERENCES}

1. S. Komatsu, H. Nakai, "Study on free vibration of curved bridge", Transaction of the Japanese Society of Civil Engineers 136: 35-50, 1966.d

2. S. Komatsu, H. Nakai, "Fundamental study on force vibration of curved bridge", Transaction of the Japanese Society of Civil Engineers 2(1), 1970.

3. C.H. Yoo, J.P. Fehrenbach, "Natural frequency of curved girder", ASCE Journal of the Engineering Mechanics Division 107: 337-354, 1981

4. C.H. Kou, S.E. Bentley, J.H. Huang, and D.A. Firmage, "Free vibration analysis of curved thin-walled girder bridges", ASCE Journal of Structural Engineering 118(10): 2890-2910, 1992.

5. W.P. Howson, A.K. Jemah, "Exact out of plane natural frequencies of curved timoshenko beams", ASCE Journal of the Engineering Mechanics, Vol.125, No. 1, 1999.

6. D. Shan, "Curved-girder bridges and vehicles coupled vibration analysis and design study of the long-span curved-girder bridges in high-speed railway”,PHD thesis, Southwest Jiaotong University, China, 1999.

7. Y. Yang, C. Wu, "Dynamic response of a horizontally curved beam subjected to vertical and horizontal moving loads", Journal of Sound and Vibration 242(3): 519-537, 2001.

8. L. Fryba, "Vibration of solids and structures under moving loads". New York: Thomas Telford, 1999.

9. J.E. Akin, M. Mofid, "Numerical solution for response of beams with moving mass", ASCE Journal of Structural Engineering 115: 120-31, 1989.

10. A.V. Pesterev, L.A. Bergman, C.A. Tan, T.C. Tsao, and B. Yang, "On Asymptotics of the Solution of the Moving Oscillator Problem”, Journal of Sound and Vibration 260: 519-36, 2003.

11. J. Martínez-Casas, E.D. Gialleonardo, S. Bruni, L. Baeza, "A comprehensive model of the railway wheelsettrack interaction in curves", Journal of Sound and Vibration 333: 4152-4169, 2014.

12. Y. Song, D. Wu, "Improvement about finite segment elements method of curved girder based on theory of spring-center method". Engineering Mechanics 28: 16-21, 2011.

13. Y. Song, D. Wu, and Q. Li, "Research of vehicle-curved bridge coupled vibration on small radius and reverse curve", Advances in Environmental Vibration for International Symposium on Environmental Vibration: 440445, 2011.

14. Y. Song, D. Wu, "Establishment of vibration differential equation and analysis of dynamic characteristics for curved beam", Advanced Materials Research 250:1329-1333, 2011.

15. Y. Song, "Study on theory and application of curved beam dynamic characteristics and train-curved bridge coupling vibration analysis", PHD thesis, Tongji University, China, 2013.

16. E.G. Dimitrakopoulos, Q. Zeng, "A three-dimensional dynamic analysis scheme for the interaction between trains and curved railway bridges". Computers and Structures 149: 43-60, 2015 


\section{LIST OF FIGURES AND TABLES:}

Fig. 1. Curvilinear coordinate system, internal forces and displacements of an infinitesimal segment

Rys 1. Układ współrzędnych krzywoliniowych, siły wewnętrzne i przesunięcia nieskończenie małego odcinka

Fig. 2. Finite element models of the curved girders in the case study

Rys 2 . Modele elementów skończonych zakrzywionych dźwigarów w stadium przypadku

Tab. 1. Comparisons of natural frequencies and modals from the proposed method and FEA

Tabela 1. Porównanie częstotliwości i modalności proponowanej metody i FEA (jednostki: $\mathrm{Hz}$ ) 


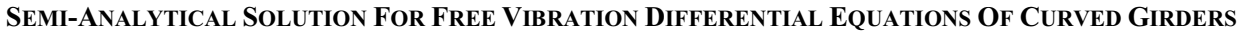

Keywords: curved girder, free vibration, natural frequency, semi-analytical solution, variable separation

\section{STRESZCZENIE:}

Jako wspólna płaszczyzna wcześniejszych badań, wynikowe równania różniczkowe drgań opracowane na podstawie statycznych równań różniczkowych Vlasowa dotyczących zakrzywionych dźwigarów nie posiadają ścisłego wyprowadzenia [1-7]. Ostatnimi czasy zastosowano metody fizyki matematycznej w celu wyprowadzenia równań różniczkowych drgań zakrzywionych dźwigarów oraz w celu udowodnienia równań, lecz rozwiązanie nadal nie zostało opracowane [8-16]. Równania różniczkowe drgań zakrzywionych dźwigarów zostały wyprowadzone zgodnie z zasadą Hamiltona oraz równaniem Lagrange'a i mają zastosowanie jedynie do zakrzywionych belek Timoshenko w osiowym układzie współrzędnych. W niniejszej pracy zaproponowano pół-analityczne rozwiązanie dla równań różniczkowych swobodnych drgań zakrzywionych dźwigarów, w oparciu o ich właściwości matematyczne i charakterystyki drgań. Przede wszystkim przyjęto podstawowe założenia dla zakrzywionego dźwigara, w tym 1) zakrzywiony dźwigar ma stały przekrój i promień krzywizny, jak również jednorodny materiał; 2) przekrój poprzeczny zakrzywionego dźwigara ma pionową oś symetrii, a centroid zbiega się z środkiem ścinania; 3) promień krzywizny zakrzywionego dźwigara jest znacznie większy niż rozmiar, długość i wysokość przekroju poprzecznego.

Rozwiązania równań różniczkowych drgań płaszczyznowych zostały podzielone na dwa rodzaje: jedno z nich bada separacje zmiennych wibracji podłużnych, podczas gdy drugie stanowi metodę syntezy dotyczącą drgania wzdłużnego oraz drgania podłużnego przy użyciu modalnego założenia Rayleigha oraz metody separacji zmiennych. Podobne podejście jest stosowane w przypadku drgań pozapłaszczyznowych, lecz dalsze operacje matematyczne są prowadzone w celu włączenia efektu zginania i skręcania.

Po pierwsze, w przypadku swobodnego drgania płaszczyznowego bez uwzględnienia podłużnego drgania, w oparciu równania różniczkowe swobodnych drgań zakrzywionych dźwigarów opracowane przez Song i Wu [14], uproszczone równania uzyskuje się przez pominięcie czynników drugorzędnych oraz osiowe odkształcenie zakrzywionego dźwigara. Ponadto, ze względu na małe odkształcenie, ignorowane jest również skrócenie krzywizny oraz jej przyspieszenie podczas zginania bocznego.

Po drugie, w przypadku swobodnego drgania płaszczyznowego z uwzględnieniem podłużnego drgania, dwie zmienne przesunięcia są niezależne od czasu, ponieważ brak jest przekroju poprzecznego? (cross-term?). Funkcja modalnego kształtu wzdłużnych drgań może zostać przyjęta z zastosowaniem metody założenia modalnego Rayleigha. Zastosowano trzy rodzaje warunków brzegowych w celu zilustrowania proponowanych rozwiązań, w tym 1) swobodnie podparty zakrzywiony dźwigar, 2) dźwigar zakrzywiony na stałe i 3) dźwigar zakrzywiony wspornie. Szczegółowe warunki brzegowe są również zawarte w równaniach.

Wreszcie, w przypadku wolnego drgania pozapłaszczyznowego, podobne uproszczenia zostały zastosowane w oryginalnych równaniach w [14]. Zignorowano sprzężenie krzywizny i jej przyspieszenie podczas pionowego zginania, 
jak również skręcanie i jego przyspieszenie. Nie stwierdzono cross-term? zmiennych przemieszczeń drgań, a funkcję modalnego kształtu pionowych drgań można poprzeć modalnym założeniem Rayleigha.

Praca przedstawia metody, szczegółowe wnioski i pół-analityczne rozwiązania dla każdej kategorii. Studium przypadku jest przeprowadzane na zakrzywionym dźwigarze z prostokątną częścią stałą przy użyciu proponowanej metody. Zastosowano metodę elementów skończonych (FEA) w celu stworzenia modelu numerycznego. Wyniki proponowanej metody i FEA są porównywane i omawiane w kategoriach częstotliwości, gdy zakrzywiony dźwigar jest poddawany wcześniej opisanym trzem warunkom brzegowym. Wyniki pokazują, że pół-analityczne rozwiązania są zgodne z rozwiązaniami dotyczącymi FEA i obserwowane są tylko niewielkie odchylenia. W przypadku płaszczyznowych drgań modalnych podczas zginania bocznego, pierwszorzędne częstotliwości uzyskane przy użyciu pół-analitycznych rozwiązań są zgodne z częstotliwościami FEA dla niewymienionych podłużnych drgań, natomiast rozwiązania te $z$ wykorzystaniem pół-analitycznej metody są nieznacznie lepsze w przypadku FEA podczas uwzględnienia drgań wzdłużnych. Możliwe wyjaśnienia mogą polegać na tym, że założona modalność jest równoznaczna z dodawaniem ograniczeń i zwiększeniem sztywności struktury, dzięki założeniu modalnemu Rayleigha. W przypadku modalności drgań pionowego zginania i skręcania pozapłaszczyznowego, pierwszorzędne częstotliwości uzyskane przy użyciu półanalitycznych rozwiązań są większe niż w przypadku metody FEA, a maksymalny błąd wynosi prawie $10 \%$. Przedstawiono dwa możliwe powody: jeden jest taki sam jak poprzednie wyjaśnienie, natomiast drugi pokazuje, że założenie trybu drgań jest całkowicie nieuzasadnione.

Na podstawie odliczenia matematycznego i wyników stadium przypadku, można wyciągnąć następujące przydatne wnioski:

1. Biorąc pod uwagę ograniczone skręcanie zakrzywionych dźwigarów, można uzyskać dokładniejsze rozwiązanie dla praktyk inżynieryjnych, zwłaszcza dla szczegółowej analizy dynamicznej zakrzywionych dźwigarów z cienkimi ściankami.

2. Równania różniczkowe wolnych drgań zakrzywionych dźwigarów z ograniczonym skrętem posiadają wyższe wartości aż do 6, które utrudniają uzyskanie rozwiązania analitycznego. W rezultacie, aproksymacja numeryczna pełni funkcję ogólnego podejścia, lecz posiada pewne ograniczenia. Proponowane pół-analityczne rozwiązanie oparte na właściwościach matematycznych zakrzywionych dźwigarów jest częściej stosowanym, ogólnym podejściem do podobnych problemów.

3. Rozwiązania częściowych równań różniczkowych posiadają oczywiste właściwości matematyczne. Metoda zaproponowana w niniejszej pracy jest przydatnym poszukiwaniem i próbą, a ewentualne doskonalenie jest warte dalszego badania. 